\title{
DEVELOPMENT OF ADMINISTRATION Professional Competences in BRAZILIAN PUBLIC UNIVERSITIES: A MULTICASE STUDY IN FLORIANÓPOLIS
}

\author{
Ednaldo de Souza Vilela ${ }^{1}$, Filipe José Dias² and Marcos B. L. Dalmau \\ ${ }^{1}$ Municipal University Center of São José, São José, Brasil \\ ${ }^{2}$ Federal University of Santa Catarina, Florianópolis, Brasil
}

\begin{abstract}
The article aims to investigate how the development of competences applied to the professional formation of the egress administrator of public municipal higher education institutions in the Florianópolis region occurs under perspective of teachers and coordinators of the bachelor's degree in administration course. For this, a qualitative and documentary research was carried out, using a structured questionnaire applied to 20 people as a data collection instrument, including 2 course coordinators and 18 professors from the studied institutions who teach the subjects whose contents are related to professional formation from the administrator. The results show that the new national curriculum guidelines encourage the development of competences. In this context, despite the effort to comply with such devices, there is some misalignment between the teaching plans and the pedagogical project of the course. Difficulties in implementing formation based on competence and lack of institutional stimuli are also perceived.
\end{abstract}

\section{KEYWORDS}

Development of competences, Higher Education, Formation, Administration Course.

\section{INTRODUCTION}

The Brazilian model of higher education, regulated by the Ministry of Education of Brazil, classifies the Higher Education Institutions - IES observing the Law 9.394/96 regarding the academic organization in two types: university institutions (universities, specialized universities and university centers) and non-university institutions (Federal Technological Education Centers (CEFETs in portuguese) and Technological Education Centers (CETs in portuguese), integrated faculties, isolated faculties and higher education institutes).

Also according to the aforementioned law, regarding the administrative organization, HEIs are classified as public educational institutions when created, incorporated, maintained and administered by the Federal, State or Municipal government or private institutions when they are maintained by individuals or legal entities of private law and for profit or not (community, confessional and philanthropic).

David C. Wyld et al. (Eds): NLPTA, EDU, DSA, IoTE, VLSI, DPPR, ACITY, AIAA, CNDC - 2021

pp. 27-44, 2021. CS \& IT - CSCP 2021

DOI: $10.5121 /$ csit.2021.111903 
After the promulgation of the Brazilian Constitutional Charter on October 5, 1988, the municipal HEIs that charged monthly fees up to that year kept this right, however, the municipal HEIs that were created after that, lost this right.

In the Florianópolis region, there are two free municipal public HEIs. The Municipal University Center of São José - USJ, the first municipal university center, public and free in Brazil, and in the municipality of Palhoça there is the Municipal College of Palhoça - FMP.

Both have in common the offer of the undergraduate course in Administration, with a percentage between $70 \%$ and $80 \%$ of vacancies in their selection processes (vestibular) for its citizens, considering the municipality's need for professional qualification, aiming to meet the demands of the local market and regional, economic, social and sustainable development.

Degree courses in Administration as a business school, positioned as one of the most offered courses in the Brazilian context, in order to serve the labor market, undergo reformulations in order to adapt them to the desired professional profiles for the graduates of the course, guiding adhering to principles such as curriculum flexibility and dynamism, emphasis on general education and competences development.

Since formation aimed at developing competences requires changes in the teaching-learning process, even though there are normative standards that guide the construction of the curricula of administration courses throughout the Brazilian territory, through the National Curriculum Guidelines (DCN in portuguese), it was raised the following question: How is the development of competences in the professional formation of administrators in public municipal HEIs in the Florianópolis region under perspective of teachers and course coordinators?

In order to answer this question, the general objective of this study was to investigate how the development of competences applied to the professional formation of administrators in public municipal HEIs in the Florianópolis region, under perspective of teachers and course coordinators, takes place. the specific objectives are: (i) it seeks to ascertain whether the competences described in the National Curriculum Guidelines of the Administration course are included in the Courses Pedagogical Projects of the studied HEIs; (ii) analyze subject programs to verify if they express which competences are developed (professional subjects); (iii) identify practices used to develop competences in the professional formation of administrators (professionalizing disciplines) and (iv) propose strategies (Identify through research carried out good practices that should be stimulated/multiplied) to meet the needs of competences development.

It is important to highlight that this study is delimited to the analysis from the perspective of municipal HEIs in the Florianópolis region, responsible for the formation of intellectual capital in these cities in recent years, whose offer of the aforementioned on-site course was also due to the demand of the region, which claimed qualified human resources to compose the companies' workforce. The study is justified by providing the professors and coordinators of the researched Business Administration course with information about the profile of the administrator that companies in Florianópolis expect, so that they can self-assess and provide subsidies for these studied HEIs to assess whether there is a need to renew its Pedagogical Policies. 


\section{TheORETICAL FOUNDATION}

\subsection{Competence}

Defining competence is not a simple task, due to its use in different areas and under different perspectives.

First of all, we know and understand that there are two terms and meanings about the main subject: competence and competency. The first one refers to an individual's capacity to perform and fulfill job responsibilities. In another point of view, competency focuses on an individual's actual performance in a particular situation.

For P. Perrenoud (1999), competence is the ability to articulate a set of schemes, thus going beyond knowledge, enabling knowledge to be mobilized in the situation, at the right time and with discernment.

To A. Zabala (2010),

The use of the term "competence" is a consequence of the need to overcome a teaching that, in most cases, was reduced to a memorizing learning of knowledge, a fact that implies difficulty for this knowledge can be applied in real life.

The competency-based formation model has, at its foundations, the orientation of formation for the development of competences that are replicable in the work environment (F. Vargas et al, 2001).

Conforming to the studies by E.P. Rossoni (2013), there are three currents that deal with the topic: American, English and French (A.S. Godoy.Et.Al., 2009; and R.C. Guimarães, 2009) and that when carrying out a literature review A.S. Godoy et al. (2009, p.267) observed that among the authors used a common point about the notion of competence is its derivation based on the "set of knowledge, skills and attitudes expected from people, the so-called in portuguese language as "CHA".

M.T.L. Fleury (2002) defines competence as the junction between theoretical knowledge (knowledge - knowing) the ability (task - knowing how to do) and being an attitude (attitude knowing how to be).

The combinations of these three resources (knowledge, skills and attitudes) or competence dimensions, applied together at work, can explain the competence of a person in conformity to G. Le Boterf (1999).

The dimensions of competence were clarified by S.T. Bergue (2014, p. 263), since, according to him, knowledge is "those conceptual or technical elements that a person has or needs to have to perform a certain activity", the competences allude to the "ability to transformation of knowledge into action" and cites as examples of skills communication, analytical capacity, flexibility, and persuasiveness.

Finally, the aforementioned author clarifies that attitudes are related to personality attributes and personal and professional posture, which reveal the "impulse of the agent for action" and examples of these are: ethical values, transparency, frankness, courtesy, cordiality, respect , among others. 
Other authors refer to attitude as social and affective aspects related to work, or a person's positive or negative reaction, their predisposition to adopt a specific action, or even a feeling, an emotion or a degree of acceptance or rejection of the person in relation to others, objects or situations (T. Durand, 2000, R.M. Gagné et.al 1988).

For M.R. Banov (2012), knowledge is the domain, the clear and correct understanding of the information in the area of expertise; skill in applying the technique, the ability to put knowledge into practice; and attitude when acting, decision making when required (dimensions of competence).

\subsection{Higher education: degree in Administration}

In historical terms, according to E.P. Rossini (2013), it was in 1952 that the first administration course was created, and the most important educational institution in Brazilian administration was founded in 1944, Fundação Getúlio Vargas - FGV, originating from national politics developmentist of President Vargas.

However, for L. Siqueira and S. Nunes (2011), the expansion in the number of administration courses is accentuated by the opening to foreign capital, based on the regulation of the profession and education, reinforced by the implementation of the government's development policy of President Juscelino Kubitscheck (1956-1960).

On September 9, 1965, through Law No. 4,769, the profession in conforming to E.P. Rossini (2013), restricting access to the professional market to holders of titles issued by the university system, and, shortly thereafter, in 1966 and later in 1993, it had its minimum curricula approved resulting in the proposal of Curriculum Guidelines for the course of Administration in 1988.

From the point of view of L. Siqueira and S. Nunes (2011), the expansion of undergraduate courses in administration occurred, mainly, in isolated colleges of the private sector, with greater concentration in the southeast and south regions of the country, whose opening was still advantageous as it does not require high investment for its implementation.

Based to data from MEC/Inep//Daes-Enade/2018, 1,765 administration courses were evaluated in the ENADE 2018 exam, of which 515 courses $(29.2 \%)$ were offered at universities, colleges presented 931 courses $(52,7 \%)$, the university centers offered $292(16.5 \%)$ and the Cefet/Ifet, in turn, offered 27 courses, corresponding to $1.5 \%$ of the total courses.

Some authors such as A. Nicolini (2003), the accelerated expansionism of undergraduate courses in administration would result in the massification of teaching and will require an innovative pedagogy so that it does not stop at stagnation, whose alternative would be for formation based on competences whose proposal discusses pedagogical methods, which oppose the "mass" formation movement in educational institutions.

Since the legislation pertaining to the teaching of Administration remained unchanged until 1993, it was with the promulgation of the new Law of Guidelines and Bases of National Education, LDB n. 9,394/96 (BRASIL, 1996), of December 20, 1996, which reopened a new debate on education, whose highlight was the insertion of the notion of competences in higher education in Brazil (L. Siqueira and S. Nunes, 2011); .

In conformity to the above authors, the Basic Guidelines Law n. 9,394/96 (LDB) allowed for the flexibility of course curricula, as long as they were linked to their curricular guidelines. 


\subsection{National curriculum guidelines - (DCNs)}

In the context of formation based on competences, this debate was intensified after Resolution $\mathrm{n}$. 4/2005 of July 13, 2005, established by the National Council of Education, together with the Chamber of Higher Education, instituting the National Curriculum Guidelines for the Graduate Course in Administration, as a guideline for the preparation of curricula in institutions of University education.

Pursuant to Resolution No. 04/2005:

1st The course's Pedagogical Project - PPC, in addition to the clear conception of the undergraduate course in Administration, with its peculiarities, its full curriculum and its operationalization, will cover, without prejudice to others, the following structural elements: (...) Art. 5 Undergraduate courses in Administration must include, in their pedagogical projects and in their curricular organization, contents that reveal interrelationships with the national and international reality, according to a historical and contextualized perspective of its applicability within organizations and the environment through the use of innovative technologies and that meet the following interconnected fields of forming: I - Basic Forming Contents: related with anthropological, sociological, philosophical, psychological, ethical-professional, political, behavioral, economic and accounting studies, as well as those related to communication and information technologies and legal sciences; II - Professional Forming Contents: related to specific areas, involving theories of administration and organizations and the administration of human resources, market and marketing, materials, production and logistics, financial and budgeting, information systems, strategic planning and services; III - Contents of Quantitative Studies and their Technologies: covering operational research, game theory, mathematical and statistical models and application of technologies that contribute to the definition and use of strategies and procedures inherent to administration; and IV - Complementary Forming Contents: optional transversal and interdisciplinary studies to enrich the trainee's profile.

This Resolution n. 4/2005 also deliberates on which competences and abilities the course should form, as described below:

I - recognize and define problems, equate solutions, think strategically, introduce changes in the production process, act preventively, transfer and generalize knowledge and exercise, in different degrees of complexity, the decision-making process; II - develop expression and communication compatible with professional practice, including in negotiation processes and in interpersonal or intergroup communications; III - reflect and act critically on the sphere of production, understanding its position and function in the production structure under its control and management; IV - develop logical, critical and analytical reasoning to operate with values and mathematical formulations present in formal and causal relationships between productive, administrative and control phenomena, as well as expressing themselves critically and creatively in the face of different organizational and social contexts; V - have initiative, creativity, determination, political and administrative will, willingness to learn, openness to change and awareness of the quality and ethical implications of their professional practice; VI - develop the ability to transfer knowledge of daily life and experience to the work environment and their field of professional activity, in different organizational models, proving to be an adaptable professional; VII - develop the capacity to prepare, implement and consolidate projects in organizations; VIII - develop the capacity to carry out consultancy in management and administration, administrative, managerial, organizational, strategic and operational opinions and expertise. (BRASIL, 2005, p. 2). 
For A. Nicolini (2003, p. 54), "desirable competences to the administrator, when they are not innate, must be developed throughout the course, a development that assumes the student as the subject of their own forming process" (A. NICOLINI, 2003, p. 54).

Based in a point of view of A.B. Silva et.al. (2007), in the professional forming process, students can help to understand the dynamics between learning and competences development if they act as an active participant in the process, which is influenced by various contexts - academic, professional and personal (social).

However, there is a new debate around higher education in Administration, since after a broad study carried out in mid-2020 by the commission of the National Education Council of the Ministry of Education (CNE/MEC), with the participation of the Federal Administration Council (CFA) and the National Association of Undergraduate Courses in Administration (Angrad), resulted in a consensus on the need to update the new National Curriculum Guidelines (DCNs) for the Bachelor's Degree in Administration course. Such changes, according to this committee, are a reflection of the development of the technological field and the market, and among the highlights of the new DCN are forming through competences and mandatory professional practice.

\section{Methodological Aspects}

This research, in order to achieve the objectives of the study, adopted an applied research, which based in the understanding of F. Appolinário (2011, p. 146), is carried out with the aim of "solving problems or concrete and immediate needs". often, these problems emerge from the professional context and can be suggested by the institution so that the researcher can solve a problem-situation.

As for the objectives, the research is documentary, because, conforming to N. Tumelero (2019), the documentary sources can be used through tables, formal documents, photos, meeting minutes, and various reports, so that in the future, the desired results can be obtained.

In this research, the PDI of the studied HEIs were used as documentary sources, as well as the Course Pedagogical Projects of their Administration courses. Regarding the approach to the problem, this is a qualitative study that is appropriate when "the researcher seeks to establish the meaning of a phenomenon from the points of view of the participants" (J.W. Creswell, 2010, p. 42 ). This research refers to two case studies in undergraduate courses in Administration and two municipal HEIs, free and public, located in the Florianópolis region, Santa Catarina.

In the point of view of M. Ludke and M.E.D.A. André (1986, p. 17), the case study, it is always well delimited, and its outlines must be clearly defined in the course of the study. The case may be similar to others, but it is at the same time distinct, as it has its own unique interest. The interest, therefore, focuses on what is unique, what is particular, even if certain similarities with other cases or situations later become evident.

The data collection instrument was structured with the objective of evaluating the perception of the coordinators of the two Administration courses of the researched HEIs and of their professors of the professional forming content disciplines, whose phenomenon (the development of competences applied to the professional formation of the administrator under perspective of teachers and coordinators) was empirically investigated in its real context. Questionnaires were used as data collection instruments that were sent to coordinators and teachers of subjects whose contents are related to the professional forming of undergraduate courses in Administration of the 
municipal HEIs of Palhoça and São José, totaling 20 teachers to whom the questionnaire was sent

From the selected sample, responses were obtained from 2 coordinators and 14 professors, being 9 (nine) professors from the USJ and 5 (five) professors from the FMP, as shown in the following Figure 1:

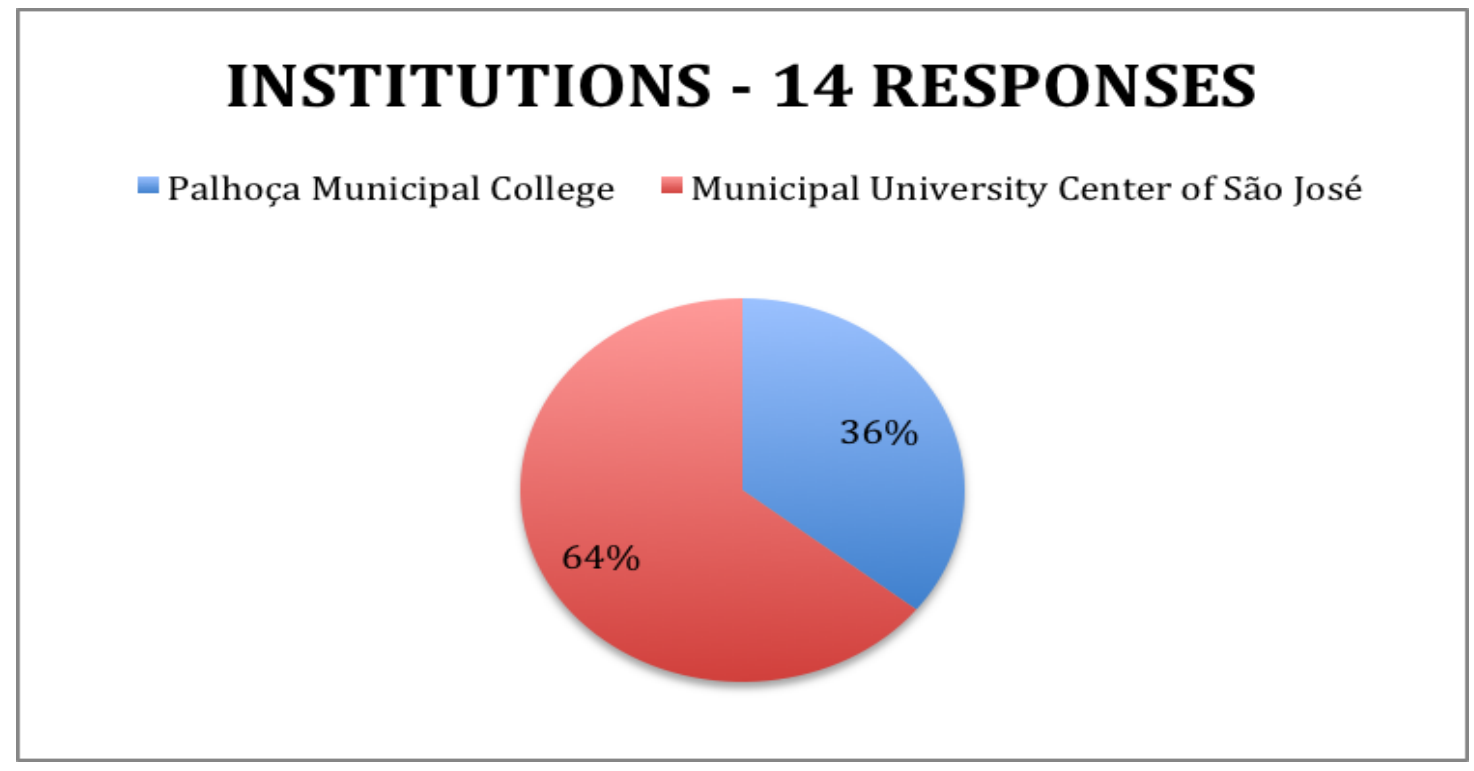

Figure 1 - Respondent Origin

In the analysis of this article, the respondents are identified as follows: $\mathrm{C} 1$ the coordinator of the (USJ) and C2 the coordinator of the (FMP). Among the professors, 9 (nine) are from USJ and identified themselves citing at this time also their discipline, such as: U1 (General Theory of Administration), U2 (Project Management), U3 (Material Management), U4 (Finance Business), U5 (Management Information System), U6 (Production Management), U7 (Marketing), U8 (Strategic Business Management), U9 (Human Resources) and 5 (five) of the FMP: F1 (People Management) , F2 (Financial Administration), F3 (General Theory of Administration), F4 (Market Research) and F5 (Market Administration). In the following topic, the analyzed results are discussed.

\section{Double Case Study: Municipal HeIs}

\subsection{Municipal University Center of São José - USJ}

The Municipal University Center of São José (USJ) was created by Municipal Law 4279 of May 15, 2005, and is the first public and free Municipal University Center in Brazil to offer the opportunity of access to free higher education with a view to entrepreneurship. and innovate the practice of municipal development with social responsibility, according to its Institutional Development Plan -PDI (2015-2019). Also based of this document, the USJ is located in the municipality of São José in Santa Catarina, and was approved by the State Council of Education on July 12, 2005, by unanimous vote, to approve the request for its accreditation granted by a favorable opinion. the operation, for two years, of the following courses: Administration, Pedagogy and Accounting. 
The USJ instituted the affirmative action public policy, with social vacancies, with $70 \%$ (seventy percent) of the total vacancies offered every six months for students who attended educational institutions maintained by the government (state, federal and municipal), being the $30 \%$ of the remaining places available to any Brazilian or foreign citizen who wants an opportunity in higher education. Then, in conformity to the PDI (2015-2019), it obtained the renewal of its accreditation for a period of five years, based on Resolution no. 27, and Opinion no. 122, of the State Council of Education, signed on May 22, 2007, and later on September 24 and 25, 2015, the institution was evaluated by a new Commission constituted by the State Council of Education, and was successful in continuing its operation, through a final concept of 3.76.

The Graduate Course in Administration at USJ is authorized to offer 80 (eighty) annual places at night, in a credit system, being divided into 40 (forty) places for admission in the first semester and 40 (forty) places for admission in the second semester, through a unified selective process (vestibular) of the Acafe System and by transfer and return, according to its Pedagogical Course Project - PPC (2020).

Based on this PPC (2020) the curriculum matrix of the Administration Course is composed of 42 theoretical subjects (2652 hours) and 1 practical subject related to the curricular internship (80 hours), organized conforming to a prerequisite logic, which must be followed during the development of the students' study, prepared accordingly with the syllabuses of the subjects of the current curricular structure. After telephone contact with the current coordinator of the Administration Course at USJ, we obtained agreement to carry out our research with her professors.

\subsection{The Municipal College of Palhoça - FMP}

The Municipal College of Palhoça - FMP is an autarchy created by Municipal Law No. 2.182, of October 25, 2005, an entity that is part of the indirect public administration of the Municipality of Palhoça with legal personality under public law, being its sponsor the Municipality of Palhoça, whose Statute and General Regulations of the FMP were elaborated in accordance with the requirements of Law 9394/96 (Law of Guidelines and Bases of National Education), which was updated and is published as Decree n. 1489/2013, based of to its Institutional Development Plan (2019-2023).

Considering to this same document, its accreditation was given by an act of the State Council of Education, which accredited the FMP by Opinion No. 056 and Resolution No. 016, of April 4, 2006, and which through Law 2386 of June 21 2006, with 80\% of the vacancies in its courses being reserved for students from public secondary schools residing in the municipality, equalizing the opportunities for admission to higher education and the other $20 \mathrm{c} / \mathrm{o}$ are available to any Brazilian or foreign citizen who wishes an opportunity in higher education. In 2010, the FMP Administration course was evaluated and recognized with a 4.02 concept by the State Council of Education of Santa Catarina.

In the terms of the Pedagogical Project of the Course - PPC (2020) of Graduation in Administration of The Municipal College of Palhoça - FMP, which is based on the Curriculum Guidelines of the Graduation in Administration Course, Resolution No. 4, of July 13, 2005, it obtained authorization based on Resolution No. 016 and Opinion No. 056 approved on 04/04/2006, recognized again for a period of 04 (four) years, based on Resolution No. 101, Opinion No. 293 of December 7, 2010, approved by Decree State n.1930, published by DOE n. 19,726 of 12.18.2013. 
Also in consideration of this document, it obtained authorization for the operation of the expansion from 100 (one hundred) vacancies to 200 annual vacancies for the undergraduate course in Administration at the Municipal College of Palhoça. Opinion 213 and Resolution CEE 112 of 08.28.2012, and Renewal of Recognition of the Bachelor's Degree in Administration course. Opinion no. 189 and Resolution n. 089 of 12.08.2015. In the aforementioned Course Pedagogical Project, it is stated that the Curriculum Matrix 2016.1 of the Graduate Course in Administration in force was approved by CONFAP Resolution 010/2016. after contact by telephone with the current coordinator of the Administration Course at FMP, we obtained agreement to carry out our research with their professors.

\section{RESULTS}

Coordinators and professors asked about "What do you understand by competence?" the following answers shown in the table below were obtained.

Table 1. Understanding of competence according to respondents

\begin{tabular}{|c|c|}
\hline $\begin{array}{l}\text { (C1) Competence is the set of knowledge, skills } \\
\text { and attitudes (cha) }\end{array}$ & $\begin{array}{l}\text { U1 Set of knowledge, skills and attitudes } \\
\text { necessary to carry out activities effectively, } \\
\text { efficiently and effectively. }\end{array}$ \\
\hline $\begin{array}{l}\text { (C2) Consists of the individual's abilities to learn } \\
\text { and develop technical and behavioral skills that } \\
\text { can be put into practice. }\end{array}$ & U2 Set of knowledge, skills and attitudes \\
\hline $\begin{array}{l}\text { F1 These are the knowledge and/or abilities of } \\
\text { an individual, perceived by other people. It } \\
\text { configures a person's behavior as it is put into } \\
\text { practice. }\end{array}$ & $\begin{array}{l}\text { U3 Competence is a person's ability to use their } \\
\text { know-how and skills to do a good job. }\end{array}$ \\
\hline $\begin{array}{l}\text { F2 Make the theory I teach useful in practice. } \\
\text { That students can apply. This is my competence. } \\
\text { Proper Didactics }\end{array}$ & $\begin{array}{l}\text { U4 Competence is a person's ability to use their } \\
\text { know-how and skills to do a good job. }\end{array}$ \\
\hline F3 Develop skills & $\begin{array}{l}\text { U5 It is an organizational requirement that } \\
\text { encompasses employees' knowledge, skills and } \\
\text { attitudes. Some theorists define attitudes as } \\
\text { behavior. }\end{array}$ \\
\hline \multirow[t]{4}{*}{$\begin{array}{l}\text { F5 Knowledge and characteristics to carry out an } \\
\text { activity. }\end{array}$} & $\begin{array}{l}\text { U6 The attributions that someone has to exercise } \\
\text { something... }\end{array}$ \\
\hline & $\begin{array}{l}\text { U7 Competence is the professional's baggage of } \\
\text { knowledge, skills and behaviors. }\end{array}$ \\
\hline & $\begin{array}{l}\text { U8 Concept involving people's knowledge, skills } \\
\text { and competences }\end{array}$ \\
\hline & $\begin{array}{l}\text { U9 Based in M.T.L. Fleury (2002), knowing how } \\
\text { to act is responsible and recognized, which } \\
\text { implies mobilizing, integrating, transferring } \\
\text { knowledge, resources, skills that add economic } \\
\text { value to the organization and social value to the } \\
\text { individual. For those who are starting the } \\
\text { administration course, we teach that competence } \\
\text { is the application of C.H.A. (Knowledge = } \\
\text { knowing; Skills = knowing how to do; Attitudes = } \\
\text { knowing how to be). Without delivery, there is no } \\
\text { competence. }\end{array}$ \\
\hline
\end{tabular}


From the results to this question, it can be seen that half of the respondents understand the concept of competence referring to the set of knowledge, skills and attitudes. Of the other respondents, some are linked to the idea of behavior.

Coordinators and professors asked about "What competences are provided to graduates of the Administration Course?" varied responses were presented as shown in the following table.

Table 2. Competences of Graduates according to interviewees

\begin{tabular}{|c|c|}
\hline $\begin{array}{l}\text { C1 I think they must have knowledge, skills for } \\
\text { the profession and necessary attitudes }\end{array}$ & $\begin{array}{l}\text { U1 Technical and behavioral knowledge, inter and } \\
\text { intrapersonal skills and ethical attitudes. }\end{array}$ \\
\hline $\begin{array}{l}\text { C2 Preparation of organizational diagnosis for } \\
\text { solving complex problems; Ability to } \\
\text { understand the social, political, economic and } \\
\text { cultural environment in which it operates and } \\
\text { make decisions that ensure the sustainability of } \\
\text { the organization and the environment; Carry out } \\
\text { planning in different areas of administration } \\
\text { considering multiple scenarios; Ability to } \\
\text { undertake a business; Ability to work in a team, } \\
\text { developing interpersonal relationships, } \\
\text { leadership and conflict management; } \\
\text { Development of critical sense, logical reasoning } \\
\text { and interpretation }\end{array}$ & U2 Manage projects \\
\hline $\begin{array}{l}\text { F1 Carry out the diagnosis to find opportunities } \\
\text { and solve problems in organizations; Develop } \\
\text { planning in different areas of administration; } \\
\text { Ability to undertake in business; Ability to work } \\
\text { with people and manage conflicts; etc. }\end{array}$ & $\begin{array}{l}\text { U3 Entrepreneurial and business management } \\
\text { skills. }\end{array}$ \\
\hline $\begin{array}{l}\text { F2 Amplified vision, action planning on what } \\
\text { was measured. }\end{array}$ & $\begin{array}{l}\text { U4 Entrepreneurial and business management } \\
\text { skills. }\end{array}$ \\
\hline F3 Being able to manage a business & $\begin{array}{l}\text { U5 Theoretical knowledge of different areas of } \\
\text { administration (people management, marketing, } \\
\text { finance, logistics), skills with administrative tools } \\
\text { (using specific systems and solving problems) and } \\
\text { attitude (interpersonal relationships, teamwork, } \\
\text { holistic view) }\end{array}$ \\
\hline $\begin{array}{l}\text { F4 Critical thinking, sense of urgency, } \\
\text { organization }\end{array}$ & $\begin{array}{l}\text { U6 Learning, technical and also living skills, } \\
\text { communication }\end{array}$ \\
\hline \multirow[t]{3}{*}{ F5 Practical activities around marketing. } & $\begin{array}{l}\text { U7 Theoretical and empirical knowledge in the } \\
\text { areas of administration, management, technical } \\
\text { skills as well as group and individual performance } \\
\text { behaviors. }\end{array}$ \\
\hline & 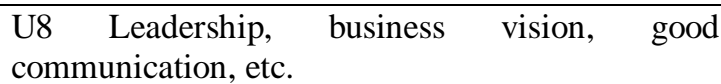 \\
\hline & $\begin{array}{l}\text { U9 Scientific knowledge; ability to analyze } \\
\text { complex problems and take action. decision; } \\
\text { career development; critical approach; leadership } \\
\text { development; team work; ability to use their } \\
\text { technical-scientific knowledge to generate process } \\
\text { improvements (innovation); development of } \\
\text { written communication and presentation; analyze } \\
\text { scenarios; among others. }\end{array}$ \\
\hline
\end{tabular}

In this aspect, it can be inferred that most of the answers obtained are incomplete and/or are not in accordance with the competences defined in the National Curriculum Guidelines. This may 
demonstrate a lack of a broad vision of the role of a particular discipline in the development of competences in professional formation.

When the coordinators were asked about the relationships between competences described in Table 2 and the Teaching and Course Pedagogical Project programs, they replied that they are fully or partially described in the programs and/or teaching plans of the subjects and that such competences are in accordance with the competences provided for in the Course Pedagogical Project. However, the competences listed in the PPC are partially developed in the Course's disciplines.

The answers in figure 2 were compared with the teaching plans of the disciplines and it was found that the competences mentioned are included in the plans as objectives of the disciplines, but many do not use the term "competence".

\section{Are the competencies described in the previous answer contained in the teaching plan?}

$$
\square \text { YES } \square \text { NO PARTIALLY }
$$

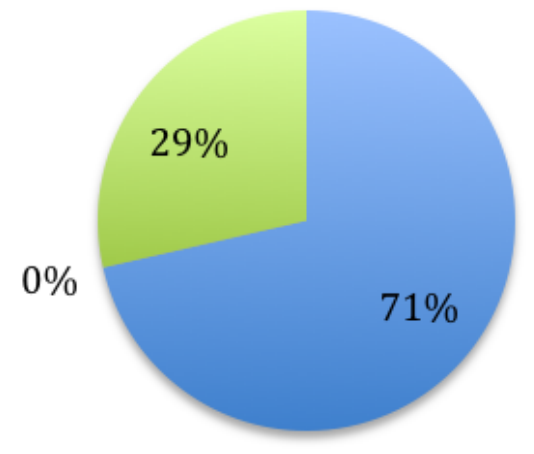

Figure 2 - Competences and Teaching Plans in the view of coordinators and the teachers

Analyzing the responses of the course coordinators as shown in figures 2, 3 and 4, it is possible to see that there is no direct association between the competences defined in the Course Pedagogical Project and the competences developed in the practices of the disciplines.

In this aspect, it appears from the As a result, due to the lack of articulation between the subjects, some competences defined in the Course Pedagogical Project are not developed during the course, which can cause some fragility in professional formation. 


\section{Are the competences described in the previous answers in accordance with the competences defined in the Pedagogical Project of the course?}

$\square$ YES $\square$ NO $\square$ PARTIALLY

$0 \%$

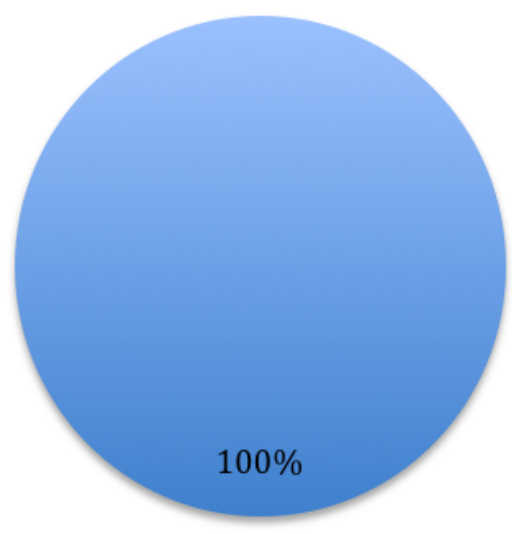

Figure 3. Competences and Course Pedagogical Project

On the other hand, the importance of developing competences is perceived when teachers are asked about the level of contribution of their discipline to the development of competence in the general education of the student.

\section{Level of contribution of your discipline to the development of competence in the student's general education.}

Little important $=$ Moderate $\quad$ Satisfactory $=$ Very important

$0 \%$

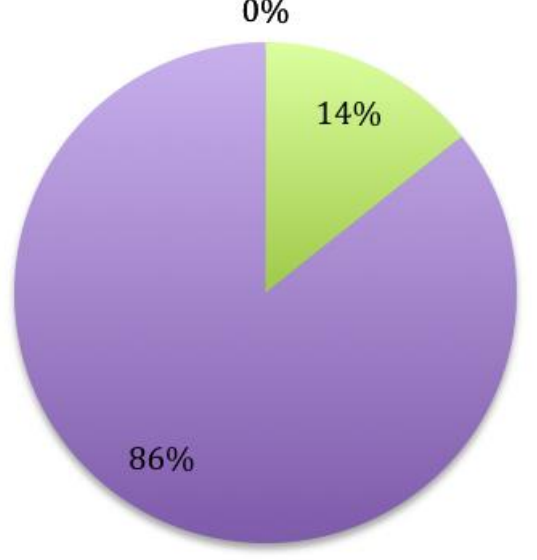

Figure 4. Competences, Course Pedagogical Project and disciplines 
Regarding the professors, asked about the strategies or tools used to develop competences in the discipline they are responsible for, the professors and coordinators responded as shown in table 3 below.

Table 3 - Strategies or tools used to develop competences?

\begin{tabular}{|c|c|}
\hline C1 Projects, etc. & U1 Team practice of theoretical issues worked on. \\
\hline $\begin{array}{l}\text { C2 The subjects must comprise theoretical, } \\
\text { practical and field classes in their workloads, } \\
\text { which promote the student's protagonism in the } \\
\text { process of developing competences }\end{array}$ & U2 Cases, Mind Maps, Canvas \\
\hline $\begin{array}{l}\text { F1 Practical activity for the preparation of the } \\
\text { TD\&E program, following the four stages of } \\
\text { planning, described in a didactic way for the } \\
\text { student to develop; Dialogue presentation of the } \\
\text { themes of the syllabus, seeking to awaken } \\
\text { interest in the student, reconciling his day to } \\
\text { day; Case studies for critical analysis and } \\
\text { problem solving; Personal development, based } \\
\text { on studies and research that promote the } \\
\text { identification of individual strengths and how } \\
\text { they can be balanced for teamwork and conflict } \\
\text { management within organizations. Flipped } \\
\text { classroom. The topic is made available and the } \\
\text { student needs to research to solve the problems } \\
\text { proposed by the teacher. }\end{array}$ & $\begin{array}{l}\text { U3 Case study, application of mathematical and } \\
\text { statistical models, debates. }\end{array}$ \\
\hline F2 Real examples. & $\begin{array}{l}\text { U4 Analysis of statements of real companies, } \\
\text { investment simulation, interpretation of financial } \\
\text { information. }\end{array}$ \\
\hline F3 Discussion and criticism of theories & $\begin{array}{l}\text { U5 Lectures on theoretical, historical and systems } \\
\text { structure study. Practical case study with systems } \\
\text { development for a chosen company, preferably a } \\
\text { small one that has everything to develop. } \\
\text { Reflective analysis by academics of the } \\
\text { development of each company presented by them. }\end{array}$ \\
\hline F4 Group work, Field research & $\begin{array}{l}\text { U6 Practical group work, with research and } \\
\text { practical exercises, videos... }\end{array}$ \\
\hline \multirow[t]{3}{*}{ F5 relationship marketing is the main one. } & $\begin{array}{l}\text { U7 Content explanatory lessons in conjunction } \\
\text { with practical lessons. Every theory envisions the } \\
\text { applied practice in which the student performs the } \\
\text { marketing function or analyzes a practical case. }\end{array}$ \\
\hline & U8 Case Studies and Concept Discussion \\
\hline & $\begin{array}{l}\text { U9 Teamwork; case studies; Presentations; } \\
\text { Preparation of reviews from technical scientific } \\
\text { readings; Debates; etc. }\end{array}$ \\
\hline
\end{tabular}

From the answers presented in Table 3, the teaching effort can be seen, but there is still some difficulty in defining and applying practices aimed at formation by competence.

The same can be seen in the respondents' answers when they are asked to share experiences of strategies or tools used for the development of competences (table 4), but in this aspect there is a greater variety of instruments. 
Table 4. Share experiences of strategies or tools used to develop competences.

\begin{tabular}{|c|c|}
\hline C1 360 degree rating. & $\begin{array}{l}\text { U1 Strong weight in the practices of reading, } \\
\text { analyzing and interpreting scientific articles with } \\
\text { further debate and conclusions on the topic } \\
\text { addressed. }\end{array}$ \\
\hline $\begin{array}{l}\text { C2 The projects will be developed by each } \\
\text { teacher in his/her discipline that makes up the } \\
\text { extension workload, and should serve } \\
\text { organizations and the Palhocense community. }\end{array}$ & $\mathrm{U} 2$ design canvas \\
\hline $\begin{array}{l}\text { F1 Exercises with the steps of a TD\&E program; } \\
\text { Case Study; Quizz; Researches; Mapping of } \\
\text { organizational competences, using Dashboard in } \\
\text { Excel }\end{array}$ & U3, U4 and U8 not answered \\
\hline F2 BPs and DREs of SA. & $\begin{array}{l}\text { U5 First, I make a theoretical overview so that } \\
\text { they have a basis on the themes. Then we go to } \\
\text { the practical part to check the organizational } \\
\text { reality. In the practical part they end up having to } \\
\text { perform with their own abilities, creativity and } \\
\text { interactivity. }\end{array}$ \\
\hline F3 Case Study Suggestions in Current Times & $\begin{array}{l}\text { U6 I use Metimeter, Jamboard as course tools, as } \\
\text { well as videos and games built by students with } \\
\text { course content }\end{array}$ \\
\hline F4 Google forms & $\begin{array}{l}\text { U7 The strategy of putting product analytics into } \\
\text { practice in every promotional compound. They } \\
\text { usually participate when they look for a product } \\
\text { in their own home to identify the logo and the } \\
\text { loyalty relationship with the product and the } \\
\text { packaging. }\end{array}$ \\
\hline $\begin{array}{l}\text { F5 I develop a marketing project that they learn } \\
\text { to work in the marketing area. }\end{array}$ & $\begin{array}{l}\text { U9 Students are given a topic to research and later } \\
\text { prepare for a class debate. On the day of class, I } \\
\text { divide the class into two groups: the first group } \\
\text { will defend the theme and the second group will } \\
\text { oppose the theme, even if the student has a } \\
\text { different view than the one he will defend. This } \\
\text { makes it possible to exercise a critical view of the } \\
\text { problems }\end{array}$ \\
\hline
\end{tabular}

Another relevant aspect in competency formation is assessment. In this sense, the professors were asked: "How are the assessments carried out to verify the development of competences in the scope of the discipline?"

Table 5. Assessment information by competence

The assessments so far are not done by competences. But to meet the DCNs, it is intended to expand
the assessment methods in the discipline, making it clear to students the competences that are being
assessed in each teaching-learning strategy, with a scale of $0-10$ for the competence being developed
in that activity. Self-assessment and teacher assessment can be done.
Through the presentation of practical work
Practical presentation of a project
Individual and team assessment
Through a set of critical reviews and debates.
Discursive evaluations involving practical cases
Evaluation where the mastery of concepts, the capacity for practical analysis and financial
management in a company, investment analysis is verified.
Financial reports and stock projection


Assessments are carried out during the application process in the organizational reality. There is a need for the student to be active and it is possible to measure their skills and attitudes precisely in this context. The transformation of the theoretical part into practice demonstrates the learning capacity and competences applied in the organization.

At this time of Covid 19 pandemic, in which we are remotely teaching assessments through exercises, case studies, assignments and tests

Through the project that is done in stages.

In the aspect of evaluation, it is noted among the answers presented in Table 5, that there is a greater variety of instruments used that aim to fulfill the task of verifying the achievement of objectives or competences in each discipline, but in this study it is not possible to define whether such instruments are sufficient and adequate for the objectives they set themselves.

And the last question was whether the institution encourages pedagogical practices aimed at formation through competences, whose answers are in figure 5:

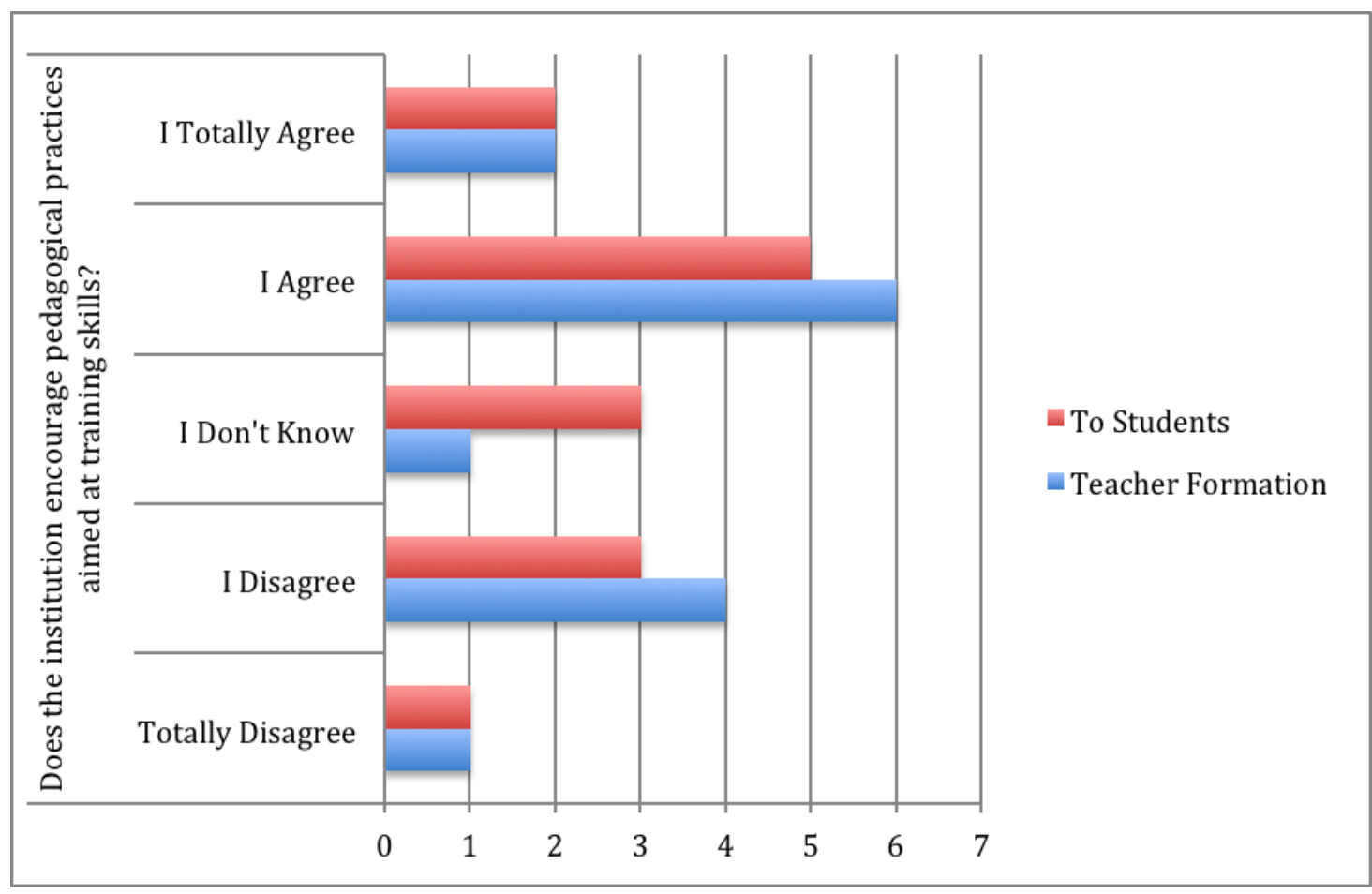

Figure 5. Stimulus Pedagogical Practices - Coordinators' and Teachers' Response

Among the responses obtained, there is a very sensitive aspect for formation based on competence in the education of students, which is the institutional incentive, both to offer support and formation to teachers and to promote a new teaching-learning format among students.

Realizes the need for the institution to promote alignment and constant formation for articulation between the competences defined in the DCN and PPC of the courses that must be developed in the subjects, and the definition, adjustments, or support for the development of strategies to promote formation based on competence.

The practice of integrated activities between the subjects and the encouragement of student practices to carry out other oriented activities outside the classroom, such as extension activities, can constitute alternatives to encourage interaction with real situations and help in the maturation 
of competences necessary for the professional practice. However, to confirm this hypothesis, further observations and studies that can solidify this view are needed.

\section{Conclusion}

The main objective of this study was to verify how the development of competences applied to the professional formation of the egress administrator of the public municipal HEIs in the Florianópolis region takes place under perspective of professors and coordinators of the Bachelor's Degree in Administration course.

Therefore, a theoretical survey was carried out on the understanding of competence and the competences defined in the National Curriculum Guidelines of the Administration course and the PPCs of the Courses present in 2 municipal public institutions in Florianópolis region were analyzed.

In the analysis of the obtained results, a lack of articulation and/or association between the competences defined in the National Curriculum Guidelines, Course Pedagogical Project and those that are developed in the disciplines can be seen.

Analyzing the responses of the course coordinators, it is possible to see that there is no direct association between the competences defined in the PPC and the competences developed in the practices of the disciplines. In this aspect, it appears from the result that in the absence of articulation between the disciplines, some competences defined in the Course Pedagogical Project are not developed during the course, which can cause some fragility in professional formation.

Among the results obtained among teachers, there is an effort to develop competences in the subjects, but there is some lack of clarity in understanding the concept of competence. The difficulty is even more accentuated when it comes to the use of a strategy for the development of competences, lacking clarity about competence-based formation.

Realizes the need for the institution to promote alignment and constant formation for articulation between the competences defined in the PPC of the courses that must be developed, and the definition, adjustments, or support for the development of strategies to promote formation based on competence.

\section{REFERENCES}

[1] F. Appolinário, Dicionário de Metodologia Científica, [Scientific Methodology Dictionary] 2. Ed, Atlas, São Paulo, 2011.

[2] M.R. Banov, Recrutamento, seleção e competências. [Recruitment, selection and competences], 3. Ed, Atlas, São Paulo, 2012.

[3] S.T. Bergue, Gestão estratégica de pessoas no setor público. [Strategic people management in the public sector], Atlas, São Paulo, 2014.

[4] BRASIL. Lei no 9394, 20 de dezembro de 1996. Disponível em: http://www.planalto.gov.br/ccivil_03/leis/19394.htm.

[5] BRASIL. Ministério da Educação. (2005). [Classificação das instituições de ensino superior]. Disponível em: http://www.mec.org.br.

[6] J.W. Creswell, Projeto de pesquisa: métodos qualitativo, quantitativo e misto. [Research project: qualitative, quantitative and mixed methods] 3. Ed, Artmed, Porto Alegre, 2010.

[7] M.A. Cunha, A expansão do ensino de Administração em Curitiba e região metropolitana no período de 1997 a 2002, [The expansion of Business Administration education in Curitiba and the metropolitan region from 1997 to 2002], Seminário em Administração, 9, FEA - USP, 2006. 
[8] T. Durand, L'alchimie de la compétence, [The alchemy of competence] Revue Française de Gestion, n. 127, 2000, p. 84102.

[9] M.T.L. Fleury, As pessoas na organização. [The people in the organization] Gente, São Paulo, 2002.

[10] R.M. Gagné, L.J. Briggs, W.W. Wager, Principles of instructional design, Holt, Rinehart and Winston, Orlando, 1988.

[11] A.S. Godoy, C.S. Antonello, D.S. Bido and D. Silva, "O desenvolvimento das competências de alunos formados do curso de Administração: Um estudo de modelagem de equações estruturais." [The development of competences of graduated students of the Administration course: A study of structural equation modeling]. Revista de Administração - RAUSP, 44 (3), 2009, pp. 265-278.

[12] R.C. Guimarães, Representação social e formação da consciência crítica no curso de graduação em administração da EA-UFRGS, [Social representation and formation of critical awareness in the undergraduate course in administration at EA-UFRGS], doctoral dissertation, Porto Alegre, 2009.

[13] G. Le Boterf,, Competence et navigation professionnelle.[ Competence and professional navigation] Éditions d' Organisation, Paris, 1999.

[14] M. Ludke, M.E.D.A de André, Pesquisa em educação: abordagens qualitativas, [Education research: qualitative approaches], Pedagógica e Universitária, São Paulo, 1986.

[15] Nicolini, "Qual será o futuro das Fábricas de Administradores?" [What will be the future of Administrator Factories?]. Revista de Administração de Empresas, São Paulo, v. 43, n. 2, 2003, p. 4454.

[16] P. Perrenoud, Avaliação: da excelência à regulação das aprendizagens, [Assessment: from excellence to learning regulation], Editora Artes Médicas Sul, Porto Alegre, 1999.

[17] E.P. Rossoni, O desenvolvimento de competências na formação do administrador: um estudo na Universidade Federal de Rondônia, [The development of competences in the training of administrators: a study at the Federal University of Rondônia], doctoral tesis, Federal University of Rio Grande do Sul, Porto Alegre, 2013.

[18] A.B. Silva, A. Alberton, M.A. Verdinelli, As Competências Profissionais do Administrador e suas Implicações na Formação Acadêmica. [The Professional Competences of the Administrator and Their Implications for Academic Formation], I Encontro de Ensino e Pesquisa em Administração e Contabilidade, EnEPQ - Anpad, Recife, 2007.

[19] L. Siqueira and S. C. Nunes, "Um olhar sobre o Projeto Pedagógico e as práticas docentes baseados na Proposta de Formação por Competências." [A look at the Pedagogical Project and teaching practices based on the Skills Training Proposal]. Administração: Ensino e Pesquisa, vol. 12, núm. 3, julio-septiembre, 2011, pp. 415-445

[20] N. Tumelero, Pesquisa documental: conceito, exemplos e passa a passo, [Document research: concept, examples and step by step], https://blog.mettzer.com/pesquisa-documental/ (2019).

[21] F. Vargas, F. Casanova, L. Montanaro, El enfoque de competência laboral: manual de formación, [The focus on labor competence: training manual], Cinterfor/OIT, Montevideo, 2001.

[22] Zabala, Como aprender e ensinar competências. [How to learn and teach skills], Penso, Porto Alegre, 2010. 


\section{AUTHORS}

\section{Marcos B. L. Dalmau}

Graduated in Administration from the Federal University of Santa Catarina (1999), Master's (2001) and Ph.D. (2003) in Production Engineering from the same institution. Full Professor at the Federal University of Santa Catarina. Professor of the Postgraduate Program in Administration (PPGA), at the level of Master's and Academic Doctorate and Professor of the Professional Masters in Administration University PPGAU/UFSC.

https://orcid.org/0000-0002-8620-1625

https://www.researchgate.net/ profile/Marcos_Dalmau

\section{Ednaldo de Souza Vilela}

Graduated in Accounting Sciences from the Federal University of Santa Catarina (1994) and Master in Production Engineering from the Federal University of Santa Catarina (2000). He is currently a professor - Centro Universitário Facvest, Centro Universitário Municipal de São José.

\section{Filipe José Dias}

Master in University Administration from the Federal University of Santa Catarina (UFSC) in 2019 and Bachelor of Law from the University of Vale do Itajaí (UNIVALI) in 2011. Doctoral Student in Administration - ppga/UFSC and scholarship holder of the UNIEDU/FUMDES Program. He is currently an Administrative Technician in Education at the Federal University of Santa Catarina.
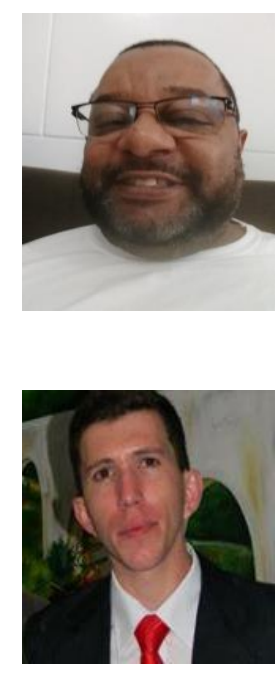

(C) 2021 By AIRCC Publishing Corporation. This article is published under the Creative Commons Attribution (CC BY) license. 